\title{
The Tenet of Corporate Social Responsibility for Environment and its Practice in Indonesia
}

\author{
Ahmad Abbas ${ }^{1}$, Wa Ode Rayyani ${ }^{2}$, Edy Fitriawan Syahadat ${ }^{3}$ \\ \{ahmad.abbas@stainparepare.ac.id ${ }^{1}$,waode.rayyani@unismuh.ac.id², edifsyahadat@unsulbar.ac.id\} \\ IAIN Parepare, South Sulawesi, Indonesia ${ }^{1}$ \\ Universitas Muhammadiyah Makassar, South Sulawesi, Indonesia ${ }^{2}$ \\ Universitas Sulawesi Barat, West Sulawesi, Indonesia ${ }^{3}$
}

\begin{abstract}
The tenet of Corporate Social Responsibility (CSR) positions the environment as logocentrism so that almost all firms increasingly desire to appear "green". However, it lacks the discussion and the response after the government of Indonesia applies the law and regulation. This paper highlights the Indonesian government role of attracting firms to be involved in carrying out the environmental performance. The tenet of legitimacy theory is reviewed to elaborate environmental CSR practice. The aim of this paper is to provide critical perspective of understanding the environmental responsibility. It posits that environmental CSR practice in Indonesia is only addressed to legitimize the business. Firms are more involved in carrying out the environmental performance due to the mandate from dominant rules and rating values enforced by the government. For an integrated synergy in maximizing sustainable development, the government should take more synergy with small firms and provide an assessment in accordance with their characteristic.
\end{abstract}

Keywords: corporate social responsibility, environment, legitimacy

\section{Introduction}

As mandated Earth Summit Rio +20 , June 2012 in Rio Jeneiro Brazil, all people in the world were doctrined to take part in conserving the environment. Government and international organization have been taking part in designing wide range of environmental management standards, labelling schemes, and reporting systems. An increasing number of firms also formulates codes of conduct and report on the environmental impacts. On the other hand, scholars and NGOs appear to demonstrate their ideas in speeches, articles, conferences by providing a sound knowledge basis to respond environmental challenge. Hence, when environmental problems have arisen, all parties should have generally held the responsibility for mitigating the environmental damage.

The tenet of environmental CSR is more implemented. It increasingly appears to be reliable program to build sustainable development. Business strategy with the label of green has been embraced by corporations. It demonstrates that most of multi-sector firms tend to be more aware of environment. They have been an active partner with society and government in conserving the environment. The environmental activities under label "go green" position environment as the forefront of CSR practices. Consequently, an increasing number of reactions of demonstrating environmental CSR leads this paper to be built. It is not for a reason that there is still considerable research gap or even firms are left with little guidance 
when they try to understand the abstract concept of environmental CSR, but it is for watching out the effectiveness of policy applied by the government. The process of building the rethoric will be in line with actual practice, if environmental CSR practice is brought coherence into the framework of theory. Furthermore, Lyon \& Maxwell have conveyed their notion regarding environmental CSR and realized still far from having a unified theory related to CSR for environment[1]. Now, this paper fortunately appears to reach their study need.

This paper points out legitimacy theory to appear superior to eloborate the development of environmental CSR. As noted by Mousa \& Hassan, it helps explain corporate environmental practices[2]. This paper is presented by a discussion elaborating some researches and actual practices related to environmental CSR. The practice of CSR lacks the discussion and response even after the regulation of government has been applicable so that this paper highlights the Indonesian government role of attracting firms to be involved in carrying out the environmental CSR. Most of the practices are being campaigned for environment and Indonesian government posits it to lead the increase of sustainable development. In report of the Ministry of Environment, most of multi-sector firms tend to be involved in conserving the environment in which the government through its regulation regarding program of rating the firm performance known as PROPER seems successful to lead firms to be more involved in performing the environmental CSR. However, it is a green sound practice in which it is interesting to discuss.

This paper is structured as follows. Brief perspective on legitimacy theory and CSR for environment is presented as literature review in this paper and further section presents the method of this paper. Section 4 discusses environmental CSR practice in Indonesia and the role of government. A discussion is provided as the response to the practice of environmental CSR in Indonesia ended by the conclusion in section 5 .

\section{Literature Review}

\subsection{Legitimacy Theory}

Legitimacy theory is actually derived from a basic concept of organizational legitimacy. It is a generalized perception or assumption that the actions of an entity are desirable, proper, or appropriate within some socially constructed system of norms, values, beliefs, and definitions[3]. It underlines three aspects consisting of perception, generalization, and social construction.

The organization described in legitimacy theory is continually seeking to ensure that it operates with the bounds and norms of their respective societies[4]. It has been the most cited theory within social economic area. Yet there remains deep discussion amongst many researchers that it has offered any real insight into CSR area [5] [6]-[9]. In any point of view, legitimacy theory is an essential point of explaining the fulfillment of life value. The attention from the external parties through a feed-back is required to achieve the value. Furthermore, legitimacy theory is the dominant perspective for explaining environmental reporting practices[2]. Firms are faced with an increasing number of environmental laws and pressure from a variety of stakeholdes regarding environmental performance. The legitimacy is achieved by exposing CSR activities. It also recognizes heterogenous competing groups of stakeholders, but it operates at the conceptual level which the tenet relates to the perception and processes involved in redefining or sustaining the perception[10]. 


\subsection{CSR for Environment}

As noted by Carroll, social responsibility must embody the economic category related to how to be profitable, the legal category related to how to obey the law, the ethical category related to how to be ethical, and the discretionary category related to how to be a good corporate citizen, making philantropic contributions in which the responsibility is purely voluntary[11]. Corporate philantropic response is not enforced under economic and legal responsibilities, it is increasingly practiced by firms and commonly viewed as a sign of good corporate citizenship[12].

Environment needs sustainability defined as the development which meets the needs of present without compromising the ability of future generations to meet their own needs. Environmental preservation becomes the great action to lead going concern and sustainable development. The integrative system is required. It will be the exact direction if the firm takes part of making decision and the regulator provides the policy. Lyon \& Maxwell perceived environmental CSR as environmentally friendly actions not required by law, also referred to as going beyond compliance, the private provision of public good, or voluntary internalizing externality[1]. Related to perspective of CSR for environment, this paper underlies a perspective that the environment is regarded as free goods and CSR covers responsibilities geared toward the reduction of the impact of environmental degradation of the operation, including such as managing waste disposal and the consumption of natural resource, recycling, putting in environmental managament system.

Business industry is depleting the environment so that prosperity and welfare of business in the long term are threatened[13]. This condition encourages firms to amend their business practice more friendly with the environment. The relationship between environment and business practice has been popular area in the research world and the effect of environment on business performance is found scholars[14], [15][16][17][18]. Firms understanding the externality would seek the idea to prevent environmental pollution, even with the release of the eco-production technology. CSR has the role for overcoming environmental pollution. It has been used to prevent the conflict. If firms ignore externality impacts, such as waste or emisson, they will be on the business pressure affecting the organizational value. The study concluded by Flammer shows that the external pressure has the effect on the value of environmental CSR[19]. Investors are likely less interested in investing capital to firms ignoring the externality. In this sense, the reputation process affects firms through environment oriented responsibility[20]. The firms' environmental performance has a beneficial effect on their financial performance through disclosure and promotion of public environmental policy or regulation in which it can lead the innovation of technology and management. Firms adopting a proactive environmental management lead into better firm performance[21].

The essence of environmental CSR is actually caused by the response of community and the reactions of environmental degradation. Business organizations have actually been understanding it. There are hundreds of companies, not a few of them ignore it. The guidance for environment has also been made by some environmental agency such as Environmental Protection Agency (EPA), European Environment Agency (EEA), Environmental Permitting Regulations (EPR), Eco-Management and Audit Scheme (EMAS) and other agencies. The guidance to assess and report environmental performance is further released, i.e Accountability (AA1000), SA8000, SIGMA, ETI, ISO26000, ACCA, and GRI. In recent times, GRI guidelines are regarded to be widely used. More than 4,000 organizations from 60 countries use it to produce the sustainability report. GRI guidelines apply to corporate 
business, public agencies, smaller enterprises, NGOs, industry group, and others. By providing the guidance for them, they are aided easily in making the report.

\section{Method}

This paper is categorized as literature review. It is designed to annotate and critique the literature and policy. It particularly discusses the topic and explores the different views so that it can provide the finding. The review is more likely to provide the primary concept of the topic showing a new framework. A literature review can be defined as a research describing, evaluating and integrating the concept. Cooper stated that it seeks to describe, summarize, evaluate, or even clarify information based on primary report [22]. Literature review paper provides the summary and critical analysis of the relevant available research and non-research literature [23], [24]. The focus of this paper, however, is to summarize and synthesize the arguments to present the finding.

This paper actually is designed to annotate and critique the literature in the CSR field and highlight and explore its development. It highlights the environmental CSR practices occurred all this time in Indonesia. Data are obtained from the Central Bureau of Statistics of Indonesia used to synthesize the argument. This paper focuses on manufacture industry because its waste is vulnerable with the the damage of environment and the industry has sensitive effect on the production growth affecting the national economy. Data in this paper cover the period of 2010-2013. This paper also integrates the data with the content of primary report obtained from the book of Ministry of Environment in Model Corporate Social Responsibility for Environment of 2014.

\section{Result and Discussion}

\subsection{Environmental CSR Practice in Indonesia}

Budget of CSR is so high showing approximately twelve trillion rupiahs per year. It is addressed to all aspects including social charity, empowerment, and environmental preservation. The government is paying attention to social and environmental activities. Based on the report of Ministry of Environment in Model Corporate Social Responsibility for Environment of 2014[25], the practice was implemented by some large firms in Indonesia. It is shown in Figure 1 pointing out distribution patterns of implementing environmental CSR with black and gray colours.

Indonesian government has been very proactive to regulate firms more involved in performing CSR since 2012. In April $4^{\text {th }}$ 2012, the government released Government Regulation No. 47/2012 regarding CSR and Environment for Limited Company. The regulation No.47/2012 is directly mandated by Law No. 40/2007. The role of regulation has been applicable, even seriousness of the government could been seen in the release of book of CSR model for environment. It intends to provide the examples of environmental CSR model. The government also creates the program to appreciate environmental CSR performed by Indonesia firms. It is a firm performance rating program and aims to lead firms to comply with the regulation known as PROPER with the purpose of maximizing green sustainability. Firms with high PROPER are regarded having good environmental performance. In recent 
times, PROPER has totally been implemented. There is the positive impact of implementing PROPER in which it has reduced the organic waste pollutions about $56 \%$, however it has still not maximized to increase the environmental quality. The government role will not been maximal if a lot of firms are not involved. Based information on the Ministry of Environment more than a quarter of 2,000 firms in Indonesia had still not complied with the regulation[26].

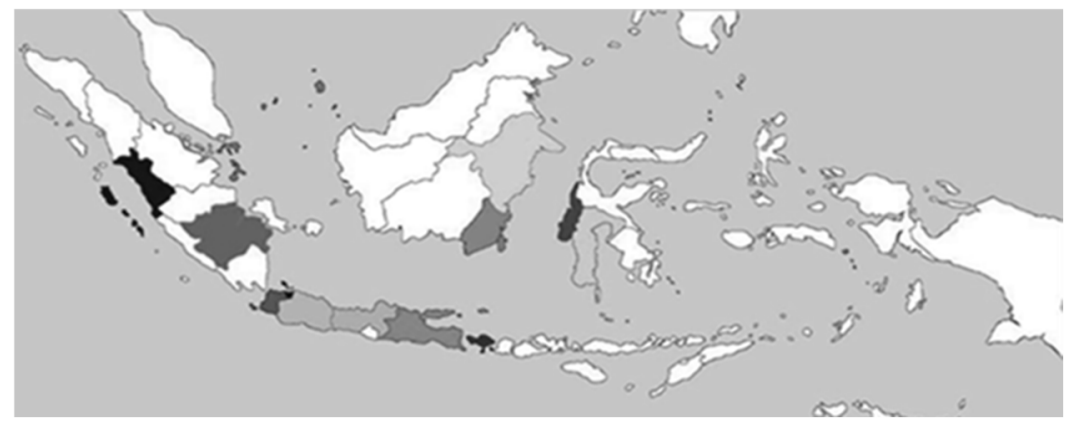

Fig.1. Distribution of Implementing CSR for Environment

Banking, manufacture, and telecomunication are types of industry more disclosing CSR activities. Indeed, each industry has the trend of CSR orientation. The disclosures of agriculture and mining groups tend to emphasize on the environment issue, of property, real estate, and building construction emphasize on the labor issue, of finance and trade as well as service and investment emphasize on the society issue. In manufacture sector, the disclosures emphasize on kinds of issues, such as basic and consumer goods industries emphasize on the labor and miscellaneous industries emphasize on the environment. The research concluded by Hadi shows that total CSR disclosure is dominated by manufacture industries with 567 items[27]. In banking firms, environmental responsibilities were higher than society and human rights.

\subsection{CSR for Environment under the Tenet of Legitimacy}

Since firms are more frequently judged on the basis of their environmental stewardship, the term of CSR for environment appears as the benchmark in assessing environmental performance. Almost every external aspect of the firm has been integrated into a more valuated tenet of legitimacy. Legitimacy concept has become one the best in reflecting the modern understanding of firms integrated with environment. It can be still generally accepted concept of legitimacy. Legal responsibility is the basic point of identifying legitimacy theory. It refers the fulfilled social contract and has also laid down the ground rules, both regulation and law. CSR for environment under the tenet of legitimacy needs the ground rules, either the law or the regulation and expects the fulfillment of corporate life value. Firms seek to gain by using environmental reporting as a part of keeping the legitimacy. From legitimacy lens, firms attempt to disclose environmental CSR with purpose of attracting capital and building a more successful business image through appreciation coming from either the government in the form of reward or society in the form of interest to purchase the product. Haniffa \& Cooke implied that the influence type on disclosure may depend on how critical the firm feels the economic activity impacts on the society[28]. Moreover, the environmental perfomance has the effect on financial performance and value satisfaction could be additional effect from a process of building business image. In this sense, the effect on financial performance has not 
been able to be postulated because If environmental policies have the most of actual significance, all firms would race to implement the environmental CSR. In the actual practice, the most of involvements come from prestigious large firms.

Firms are ideally involved in environmental CSR because they are mandated by the dominant norms, rules, and values coming from society, but its practice Indonesia encourages firms more involved because there is a requirment under law and government regulation. Thus, environmental CSR practice is referred to an action which also requires the law and regulation.

The concept of legitimacy is important utilized to analyze environmental CSR practice conducted by firms. The relationship between firms and their environment could be leading the fulfillment of corporate value. Firms tend to use performance based on environment because they are being rated. Firms will always attempt to comply with the law and regulation and to bring the norms as the purpose of fulfilling their business value. When they do it, legitimacy is perceived. Legitimacy will appear with a perception coming from the government and the society due to a reaction of the society and the government as they see it.

\subsection{The Response to Environmental CSR Practice in Indonesia}

The Indonesian government always hopes that the operated firms at least prevent impacts of externality such as eliminating waste and emissions, maximazing the efficiency and productivity of its resource, and minimizing practices which might adversely affect the enjoyment of country's resource of future generations. However, PROPER is only complement for the previous regulation in Indonesia, namely AMDAL referred to the analysis regarding environmental impact. Because it is regarded less effective to regulate firms, PROPER emerges.

Indonesian government has led firms to comply with the regulation through PROPER. The essential point of PROPER only provides status of compliance with purpose of building more business image. The status of compliance is a value given by the government. It is marked with colour of blue, red, and black. Blue is regarded compliance with the regulation and red and black are regarded noncompliance. In other word, PROPER made by the government is only providing the incentive of reputation and firm with compliant status of PROPER is viewed more likely to attract capital or propose credit. If people say environmental CSR as part of building business image, it will be right. Inevitably, the image is the simultaneous effect in which strategic legitimacy covers it. Environmental CSR practice under law and regulation is only addressed to legitimize the business. If they do not obtain legitimacy for their business, environmental CSR will be only the green sound practice.

However, there are still few firms viewing that PROPER needs time, cost, and huge attention to be involved and even does not bring beneficial to the firm performance. PROPER is recently more participated by large firms racing to achieve the highest rating, such as Holcim Indonesia given with gold rating and Adaro Indonesia, Unilever, and Semen Gresik given green rating in 2012. It may be one the best way to legitimize their business. How to other industries, they are still reluctant to participate because PROPER is regarded complex and less beneficial to their business performance. Otherwise, several industries have been participated, but they may be reluctant to upgrade their rating to be high (gold and green). They are likely to regard PROPER as just attendance and in the form of response to the regulation made by Indonesian government.

Manufacture industry has the high sensitive effect on the production growth. The rate of production growth is rapid. As noted by Statistics Indonesia[29], manufacture industry has the 
role in Indonesian economy in which it has been contributed since 1991 and the first rank in GDP, about $85 \%$ of total GDP. The brief summary of production growth is shown in Table 1 .

Table 1. Manufacture production growth

\begin{tabular}{|c|c|c|}
\hline Year $(t-t+1)$ & Large and Medium & Micro and Small \\
\hline $2012-2013$ & $5.64 \%$ & $7.51 \%$ \\
\hline 2011-2012 & $4.12 \%$ & $4.06 \%$ \\
\hline $2010-2011$ & $4.10 \%$ & $4.71 \%$ \\
\hline Industry Scale & Group & $\%$ \\
\hline \multirow{8}{*}{ Large and Medium } & Vehicles & 11,48 \\
\hline & Non-machines and equipments & 11.37 \\
\hline & Foods & 10.77 \\
\hline & Metals & 10.57 \\
\hline & Printing and Recording Media & 9.42 \\
\hline & Computer, Electronic, and Optic & 9.32 \\
\hline & Clothes & 8.41 \\
\hline & Chemicals & 6.65 \\
\hline \multirow{11}{*}{ Micro and Small } & Foods & 17.58 \\
\hline & Computer, Electronic, and Optic & 16.57 \\
\hline & Metals & 12.07 \\
\hline & Beverage & 11.79 \\
\hline & Leathers & 9.32 \\
\hline & Clothes & 8.52 \\
\hline & Textiles & 8.19 \\
\hline & Chemicals & 6.82 \\
\hline & $\begin{array}{l}\text { Reparation Service and Installation of the } \\
\text { Machine }\end{array}$ & 6.66 \\
\hline & Rubbers and Plastics & 6.27 \\
\hline & Pharmacy and Medicine & 5.24 \\
\hline
\end{tabular}

Over the period of 2011-2013, their production growth tended to increase. From 2012 to 2013, the level of production growth of large and medium manufacture increased approximately 5,64 \% and the level of production growth of micro and small manufacture increased approximately $7.51 \%$. The production of micro and small manufactur tends to increase competitively. From 2012 to 2013, it indicated that the raise of production growth of small and micro manufacture nearly reaches one and a half times higher of the production growth of large and medium manufacture.

Environmental performance may tend to increase, but the rate of production growth inevitably increases at all times. One of industries having the high sensitive effect on the production growth is manufacture. The rate of production growth in the manufacture industry is rapid. The government role should emphasize more on small firms because the production growth of small firms tends to increase competitively. For example, in manufacture industry, as noted in Table 1 that the production growth of small and micro manufacture in period 2013 was higher than the production growth of large and medium manufacture. The government should provide appropriate regulations in order firms could participate in conserving the environment in accordance their characteristic. Business performances of small firms are presumably not regular and not related to strategy to build the image or reputation based on 
environmental CSR. It is necessary to understand the special characteristic of small firms. Vives stated that many small enterprises are family-owned firms, or privately held by a small group of shareholder so that they have close relationship between management and ownership making it eaiser align the objectives of both[30]. It means that ownership and management are often not separated and the relationship between stakeholder and CSR is an informal character[31]. There is also no empirical evidence that environmental CSR contributes the financial performance. They are presumably to have no brand and resource to plant risk management activities. As argued by Jenkins, as long as CSR is a risk management tool for large firms, it is not true for small enterprises[32]. Small enterprises are not as much visible as large enterprises. The purpose of them is likely to avoid the risk, not to mitigate the risk.

The increase of environmental practice is caused by the emergence of law and regulation made by government. Nowadays, some firms have been doing the environmental CSR practice because of the regulation. Awareness of firms bound by regulation tends to have a high degree of involvement. Large firms tend to have a higher degree of participation in doing environmental CSR than small firms. The compliance with law and regulation has been a benchmark made by the government in evaluating environmental performance carried out by firms. It is mostly applied by them due to the pressure of regulation. Some firms are likely to neglect the requirement of regulation. The reason is that good rating provided by the government regulation is regarded not to bring more beneficial for them. That is why, some firms particularly for small firms are reluctant to be involved. They also consider that their business is less coming from the brand image and reputation and viewing that the huge response is only addressed to public firms.

\section{Conclusion}

Firms are more involved in environmental CSR because they are mandated by the dominant rules and values established by the government. Mandatory responsibilities based on the law and regulation do necessarily works toward real environmentally responsible behavior. Environmental CSR practice in Indonesia has been regarded as the legal responsibility. It is not under the pressure of financial growth, but firms apply environmental CSR because of the pressure of regulation.

This paper has demonstrated that legitimacy theory brings coherence into the practice of CSR for environment. It has been widely accepted that CSR for environment has the ability to encourage firms in gaining the legitimacy and the movements to maximize sustainable development are supported by the law and regulation. As a critical perspective of providing an understanding of environmental CSR practice, the result of this paper is documented to the literatures of CSR. CSR for environment emphasizing on the tenet of legitimacy that it is one of the most common theories utilized. The result is also addressed to the government providing an assessment in accordance with firm characteristic. For an integrated synergy in maximizing susitainable development, the government should also take more synergy with small firms. Moreover, this paper regards that the literatures related to CSR have tended to ignore small firms. For future paper, it is considerable to be more explored. Last but not least, the authors forecast ten years later, there will be a rich literature that will stimulate scholars, professionals, policy makers, and business organizations to revisit this paper and provide the idea in the context of environmental corporate responsibility. 


\section{References}

[1] T. Lyon and J. Maxwell, "Corporate Social Responsibility and the Environment: a Theoretical Perspective," Rev. Environ. Econ. Policy, vol. 1, no. 1, pp. 1-22, 2008.

[2] G. A. Mousa, et. al., "Legitimacy Theory and Environmental Practices: Short Notes," Int. J. Bus. Stat. Anal., 2015, doi: 10.12785/ijbsa/020104.

[3] M. C. Suchman, "Managing Legitimacy: Strategic and Institutional Approaches," Acad. Manag. Rev., 1995, doi: 10.5465/amr.1995.9508080331.

[4] C. M. Deegan, Financial Accounting Theory 4E. 2014.

[5] S. Cuganesan, L. Ward, and J. Guthrie, "Legitimacy theory: A story of reporting social and environmental matters within the Australian food and beverage industry," ... Interdiscip. Res. ..., 2007.

[6] J. A. Enahoro, "Legitimacy for Accounting for Environmental Degradation and Pollution," Eur. Sci. J. Febr. Ed., 1857.

[7] H. Tregidga, M. Milne, and K. Kearins, "Organisational Legitimacy and Social and Environmental Reporting Research: The Potential of Discourse Analysis," 5th Australas. Conf. Soc. Environ. Account. Res., 2006.

[8] S. Van Der Laan, "The role of theory in explaining motivation for corporate social disclosures: Voluntary disclosures vs ' solicited ' disclosures," Australlasian Bus. Financ. J., 2009.

[9] P. Vourvachis, In search of explanations for corporate social reporting (CSR): an attempt to revisit legitimacy theory. 2008.

[10] L. Moerman and S. Van Der Laan, "Social reporting in the tobacco industry: All smoke and mirrors?," Accounting, Audit. Account. J., 2005, doi: 10.1108/09513570510600747.

[11] A. B. Carroll and A. B. Carroll, "Three-Dimensional Conceptual Model of Corporate Performance," Source Acad. Manag. Rev., 2008.

[12] "Book Reviews," Dev. Change, 1997, doi: 10.1111/1467-7660.00039.

[13] S. Medarevic, "Environmental Corporate Social Responsibility and the Carbon Economy : A Case for CSR , the Triple Bottom Line and Obliquity," Corp. Gov. eJournal, 2012.

[14] S. A. Al-Tuwaijri, T. E. Christensen, and K. E. Hughes, "The relations among environmental disclosure, environmental performance, and economic performance: A simultaneous equations approach,” Accounting, Organ. Soc., 2004, doi: 10.1016/S0361-3682(03)00032-1.

[15] G. Filbeck and R. F. Gorman, "The Relationship between the environmental and financial performance of public utilities," Environ. Resour. Econ., 2004, doi: 10.1023/B:EARE.0000044602.86367.ff.

[16] Y. Nakao, M. Nakano, A. Amano, K. Kokubu, K. Matsumura, and K. Gemba, "Corporate environmental and financial performances and the effects of information-based instruments of environmental policy in Japan," Int. J. Environ. Sustain. Dev., 2007, doi: 10.1504/IJESD.2007.012739.

[17] I. B. Suratno, Darsono, and S. Mutmainah, "Pengaruh Environmental Performance Terhadap Environmental Disclosure dan Economic Performance," Simp. Nas. 9 Padang, 2006.

[18] A. Wang, "Dimensions of Corporate Social Responsibility and Advertising Practice," Corp. Reput. Rev., 2008, doi: 10.1057/crr.2008.15.

[19] C. Flammer, "Corporate Social Responsibility and Stock Prices : The Environmental Awareness of Shareholders," Acad. Manag. J., 2013.

[20] M. Khan, D. A. Majid, D. M. Yasir, and M. Arshad, "Corporate Social Responsibility and Corporate Reputation: A Case of Cement Industry in Pakistan Majid Khan Dr . Abdul Majid Dr . Muhammad Yasir Muhammad Arshad," Interdiscip. J. Contemp. Res. Bus., 2013.

[21] M. D. López-Gamero, J. F. Molina-Azorín, and E. Claver-Cortés, "The whole relationship between environmental variables and firm performance: Competitive advantage and firm resources as mediator variables," J. Environ. Manage., 2009, doi: 10.1016/j.jenvman.2009.05.007.

[22] H. M. Cooper, "Organizing knowledge syntheses: A taxonomy of literature reviews," Knowl. Soc., 1988, doi: 10.1007/BF03177550. 
[23] C. Hart, "Doing a Literature Review: Releasing the Research Imagination," Journal of Perioperative Practice. 2018.

[24] P. Cronin, F. Ryan, and M. Coughlan, "Undertaking a literature review: a step-by-step approach.," British journal of nursing (Mark Allen Publishing). 2008, doi: 10.12968/bjon.2008.17.1.28059.

[25] State Minister for Environment, "Report of the Ministry of Environment in Model Corporate Social Responsibility for Environment 2014,” 2014. [Online]. Available: www.menlh.go.id.

[26] Ekuatorial, "Seperempat Perusahaan Indonesia Tak Taat Lingkungan," 2014. http://ekuatorial.com/energy/moef-71-percent-out-of-2000-companies-comply-to-environmentregulations.

[27] N. Hadi, "Interaksi Tanggung Jawab Sosial, Kinerja Sosial, Kinerja Keuangan dan Luas Pengungkapan Sosial (Uji Motif di Balik Social Responsibility Perusahaan Go Publik di Indonesia)," Maksimum, 2011.

[28] R. M. Haniffa and T. E. Cooke, "The impact of culture and governance on corporate social reporting," J. Account. Public Policy, 2005, doi: 10.1016/j.jaccpubpol.2005.06.001.

[29] [BPS] Badan Pusat Statistik, "Berita resmi statistik," Bps. Go.Id, 2019.

[30] A. Vives, "Social and Environmental Responsibility in Small and Medium Enterprises in Latin America," J. Corp. Citizsh., 2014, doi: 10.9774/gleaf.4700.2006.sp.00006.

[31] G. Málovics, N. N. Csigéné, and S. Kraus, "The role of corporate social responsibility in strong sustainability," J. Socio. Econ., 2008, doi: 10.1016/j.socec.2006.12.061.

[32] H. Jenkins, "A Critique of Conventional CSR Theory: An SME Perspective," J. Gen. Manag., 2004, doi: 10.1177/030630700402900403. 